\title{
Evidence for adsorption of chlorine species on iron(III) (hydr)oxides in the Sheepbed mudstone, Gale crater, Mars
}

T.S. Peretyazhko ${ }^{1}$, S.J. Ralston ${ }^{1}$, B. Sutter ${ }^{2}$, D.W. Ming $2 .{ }^{1}$ Jacobs, NASA Johnson Space Center, Houston, TX 77058 (tanya.peretyazhko@nasa.gov), ${ }^{2}$ NASA Johnson Space Center, Houston, TX 77058

Introduction: Chlorine is a widespread element on Mars present in dust, soils and rocks, including the Sheepbed mudstone at Yellowknife Bay, Gale crater [1]. Combined elemental and volatile analyses of two drilled samples, Cumberland and John Klein, indicated that chloride $\left(\mathrm{Cl}^{-}\right)$and perchlorate $\left(\mathrm{ClO}_{4}^{-}\right)$are likely present in the mudstone [1]. The nature of chlorine species in Sheepbed mudstone is still not well constrained. It has been proposed that both are present as amorphous or crystalline salts physically mixed with mudstone minerals [2-4]. We alternatively hypothesize that adsorbed perchlorate and chloride exist in the mudstone and adsorption could occur, in particular, on Fe(III) (hydr)oxide phases as supported by laboratory observations on terrestrial materials [5]. Mineralogical and compositional analyses of the drilled Cumberland mudstone sample revealed the presence of $\sim 30 \mathrm{wt} \%$ of a Fe-rich X-ray amorphous phase [6]. Ferrihydrite has been proposed as a component of the Fe-rich X-ray amorphous material [7].

The objectives of this work were to determine adsorption of perchlorate and chloride on ferrihydrite and to enable data comparison by characterizing adsorbed chloride and perchlorate with thermal and evolved gas analysis run under operating conditions similar to the SAM instrument onboard the Curiosity rover.

Materials and Methods: Fresh and aged ferrihydrite were used in adsorption experiments. Ferrihydrite was prepared by grinding a mixture of $20 \mathrm{~g}$ $\mathrm{Fe}\left(\mathrm{NO}_{3}\right)_{3} \cdot 9 \mathrm{H}_{2} \mathrm{O}$ and $12 \mathrm{~g} \mathrm{NH}_{4} \mathrm{HCO}_{3}$ [8]. Fresh ferrihydrite was used within 3 months after synthesis. Aged ferrihydrite was stored for 3 years under lab ambient conditions prior to adsorption experiments

For adsorption experiments, suspensions of $6.7 \mathrm{~g} / \mathrm{l}$ ferrihydrite were prepared by mixing $200 \mathrm{mg}$ solid phase with $29.8 \mathrm{ml}$ ultrapure water in $60-\mathrm{ml}$ plastic bottles. $1 \mathrm{M} \mathrm{HCl}$ or $\mathrm{NaOH}$ was added to reach ultraacidic ( $\mathrm{pH} 2-2.5)$, acidic ( $\mathrm{pH} 3.8-4.5)$ and near-neutral ( $\mathrm{pH}$ 6.2-7.3) $\mathrm{pH}$ conditions (Fig. 1). In order to extend chloride adsorption to near-neutral $\mathrm{pH}$ conditions, $\mathrm{NaCl}$ was used as a source of $\mathrm{Cl}^{-}$. The amount of $\mathrm{NaCl}$ was added to match the amount of $\mathrm{Cl}^{-}$added as $\mathrm{HCl}$ in the ultra-acidic and acidic samples (experiments were only performed with fresh ferrihydrite). Three replicates and three blanks (no ferrihydrite) were prepared for each $\mathrm{pH}$ range. The samples and blanks were equilibrated without shaking for $24 \mathrm{~h}$ then an aliquot of
$\mathrm{NaClO}_{4}$ stock solution was added to suspensions to achieve a perchlorate concentration of $5.2 \mathrm{mM}$. After perchlorate addition, the samples were equilibrated without shaking again for $24 \mathrm{~h}$. Immediately after $\mathrm{ClO}_{4}^{-}$ addition and after $24 \mathrm{~h}$ equilibration, $\sim 2 \mathrm{ml}$ aliquots were collected and filtered $(<0.22 \mu \mathrm{m})$ for ion chromatography (IC) analysis of dissolved $\mathrm{Cl}^{-}$and $\mathrm{ClO}_{4}^{-}$. At the end of experiments, the solids were separated from supernatant, washed twice with ultrapure water, and air-dried for thermal and evolved gas (EGA) analysis.

Results: The freshly synthesized ferrihydrite was 2line ferrihydrite as evidenced by two broad X-ray diffraction peaks, at $\sim 40^{\circ}$ and $70^{\circ} 2 \theta$. Aged ferrihydrite sample was also 2-line ferrihydrite but contained $\sim 1.9$ $\mathrm{wt} \%$ hematite.

Perchlorate adsorption varied with $\mathrm{pH}$ in the fresh and aged ferrihydrite suspensions. The amount of adsorbed $\mathrm{ClO}_{4}^{-}$decreased as $\mathrm{pH}$ changed from acidic to ultra-acidic conditions (Fig. 1a). Adsorbed perchlorate
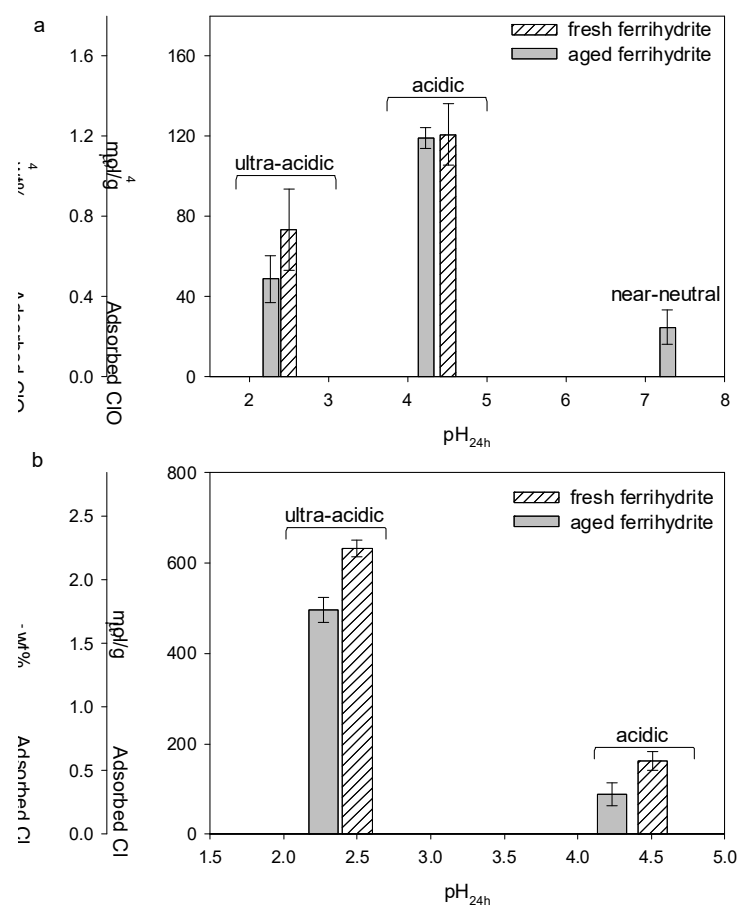

Fig. 1. Adsorbed (a) perchlorate and (b) chloride on aged and fresh ferrihydrite. No adsorbed chloride was detected under near-neutral conditions. 
was $\sim 120 \mu \mathrm{mol} / \mathrm{g}(1.2 \mathrm{wt} \%)$ and $\sim 50 \mu \mathrm{mol} / \mathrm{g}(0.5$ $\mathrm{wt} \%)$ at acidic and ultra-acidic $\mathrm{pH}$, respectively, for both ferrihydrite samples (Fig. 1a). The lower adsorption under ultra-acidic than acidic conditions was caused by chloride adsorption (0.3-2.2 wt\%, Fig. 1b). Chloride has higher affinity for adsorption surface sites and, as a result, outcompetes perchlorate for adsorbing sites. When $\mathrm{pH}$ reached near-neutral conditions, the adsorbed perchlorate decreased to $\sim 25$ $\mu \mathrm{mol} / \mathrm{g}(0.2 \mathrm{wt} \%)$ in the aged ferrihydrite and completely disappeared in the fresh ferrihydrite (Fig. 1a). Chloride adsorption on fresh ferrihydrite did not occur under near-neutral conditions.

Fresh and aged ferrihydrite samples with $\mathrm{ClO}_{4}{ }^{-}$adsorbed under ultra-acidic and acidic $\mathrm{pH}$ conditions had $\mathrm{O}_{2}$ peak at $306 \pm 1{ }^{\circ} \mathrm{C}$ which was not observed in the unreacted ferrihydrite (Fig. 2a). Based on this observations, the $306{ }^{\circ} \mathrm{C}$ peak was assigned to decomposition of adsorbed perchlorate. Oxygen release at $306^{\circ} \mathrm{C}$ was not detected in the aged ferrihydrite sample incubated under near-neutral conditions indicating that EGA was not sensitive to perchlorate content of $\sim 0.2 \mathrm{wt} \%$

Evolved $\mathrm{HCl}$ was detected in the ultra-acidic and acidic aged ferrihydrite samples and likely originated from desorption of $\mathrm{Cl}^{-}$but not $\mathrm{ClO}_{4}^{-}$. The continuous $\mathrm{HCl}$ release occurred at $>470{ }^{\circ} \mathrm{C}$ as shown for the ultra-acidic sample in Fig. 2b. The sample had two broad overlapping $\mathrm{HCl}$ peaks at $\sim 680$ and $\sim 830^{\circ} \mathrm{C}$ (Fig. 2b). The release of $\mathrm{HCl}$ did not occur in the ultra-acidic and

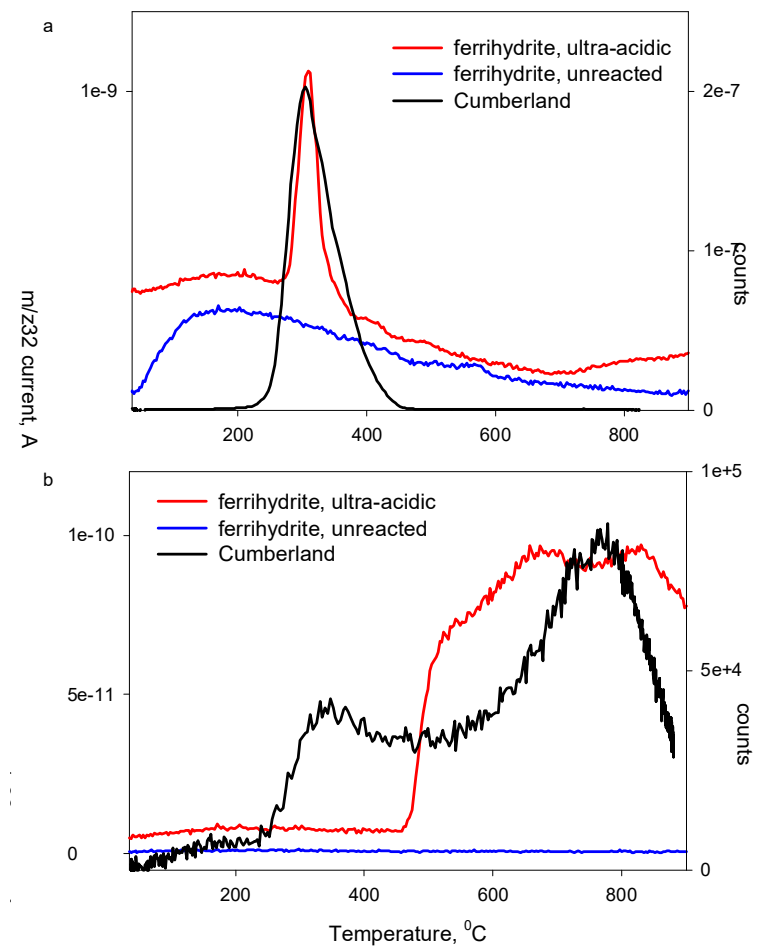

Fig. 2. Evolved (a) $\mathrm{O}_{2}$ and (b) $\mathrm{HCl}$ for aged ferrihydrite and Cumberland. acidic fresh ferrihydrite samples. Lack of $\mathrm{HCl}$ release is likely due to different $\mathrm{Cl}^{-}$desorption behavior during thermal treatment caused by ferrihydrite aging.

Discussion and Conclusions: Evolved $\mathrm{O}_{2}$ measured by the SAM instrument in Cumberland mudstone had a peak at $310{ }^{\circ} \mathrm{C}$ (Fig. 2b) assigned to the presence of up to $\sim 1 \mathrm{wt} \%$ oxychlorine phases (perchlorates and/or chlorates [1,3]). Ultra-acidic and acidic samples of aged and fresh ferrihydrite with adsorbed perchlorate had an $\mathrm{O}_{2}$ peak at $306{ }^{\circ} \mathrm{C}$ (Fig. 2a). Similar temperatures of $\mathrm{O}_{2}$ release suggests that the oxychlorine compound responsible for the $310{ }^{\circ} \mathrm{C} \mathrm{O}_{2}$ peak in the Cumberland mudstone could be attributed to perchlorate adsorbed on ferrihydrite under acidic conditons.

The Cumberland sample had an $\mathrm{HCl}$ release in the $250-800{ }^{\circ} \mathrm{C}$ temperature interval with two peaks at $\sim 340$ and $\sim 770{ }^{\circ} \mathrm{C}$ (Fig. 2b). The high temperature $\mathrm{HCl}$ release in Cumberland was within the temperature range of evolved $\mathrm{HCl}$ originated from the aged ferrihydrite, in particular, the $\mathrm{HCl}$ peak in Cumberland was in between the $\mathrm{HCl}$ peaks observed in the ultra-acidic sample (Fig. 2b). The $\mathrm{HCl}$ peak in the acidic sample $(\mathrm{pH} 4)$ was at lower temperature $\left(\sim 620^{\circ} \mathrm{C}\right)$ than in Cumberland. Comparison of evolved $\mathrm{HCl}$ in Cumberland and our samples indicates that chloride adsorbed on ferrihydrite similar to our synthetic aged ferrihydrite could be present in mudstone. Adsorption likely occurred at $\mathrm{pH}<4$.

Based on our adsorption studies and EGA analysis, both adsorbed chloride and perchlorate are likely present in Cumberland mudstone. Adsorption occurred under acidic $\mathrm{pH}<4$ conditions. Such conditions could be a result of post-depositional water-rock interactions of ferrihydrite with acid-sulfate groundwater containing dissolved chloride and perchlorate.

References: [1] Sutter et al et al. (2017) JGR Planets, [2] Sutter et al. (2015) LPSC abstract, [3] Hogancamp et al. (2018) JGR Planets, [4] Clark et al. (2019) JGR Planets,[5] Kumar et al (2014) Adv. Colloid Interface Sci, [6] Vaniman et al (2014) Science, [7] Dehouk et al (2014) JGR Planets, [8] Smith et al (2012) 